Génét. Sél. Evol., 1985, 17 (2), 283-290

Note

\title{
Electrophoretic serum protein fractions in dwarf and normal layer hens and their correlations with productive traits
}

\author{
A.H. EL-ATTAR and M.A. RASHD \\ Animal Production Department, Genetics Department \\ Faculty of Agriculture, Aïn Shams University, Cairo, Egypt
}

\section{Summary}

Normal and dwarf Fayoumi-cross layers aged 43 weeks, belonging to 7 sire families, were compared for serum protein profiles, using a Polyacrylamide gel electrophoresis technique. Phenotypic correlations between serum protein percentages and productive traits were estimated. The results were as follows :

1. Albumin p. 100 for dwarf layers represented 91.8 p. 100 of that of the normal ones $(\mathrm{p}<0.05)$.

2. Dwarf layers had significantly higher $\beta_{1}$-globulin p. $100(\mathrm{p}<0.01)$ than their normal counterparts.

3. Total globulin p. 100 was higher for dwarf layers than for the normal ones (65.53 vs 62.58 , respectively, $\mathrm{p}<0.01$ ).

4. Sire family effect was only significant for $\gamma_{1}$-globulin p. 100 , while the sire family $x$ genotype interaction did not show any significance for serum protein percentages.

5. Most of the phenotypic correlations of serum protein percentages with productive traits were insignificant. $\gamma_{2}$-globulin p. 100 was negatively correlated with body weight at 8 weeks of age.

Key words : Fowl, dwarfism, serum protein, egg production.

\section{Résumé}

Fractions électrophorétiques des protéines du sérum chez des pondeuses naines et normales et leurs corrélations avec des caractères économiques

Des poules pondeuses normales et naines d'un croisement Fayoumi âgées de 43 semaines, appartenant à 7 familles de pères, ont été comparées pour la proportion des protéines sériques, en utilisant la technique d'électrophorèse en gel de polyacrylamide. Les corrélations phénotypiques entre les pourcentages des diverses classes de protéines du sérum et les caractères de production étaient estimés. Les résultats sont les suivants : 
1. Le pourcentage d'albumine pour les pondeuses naines ne représentait que 91,8 p. 100 de celui trouvé chez les normales $(\mathrm{p}<0,05)$.

2 . Les pondeuses naines avaient un pourcentage de $\beta_{1}$-globulines significativement plus élevé $(\mathrm{p}<0,01)$ que celui de leurs homologues normales.

3. Le pourcentage total de globulines était supérieur chez les poules naines comparées aux normales $(65,5$ contre 62,6 respectivement ; $p<0,01)$.

4. L'effet de la famille de père n'était significatif que pour le taux de $\gamma_{1}$-globulines, tandis que l'interaction famille de père $\mathrm{x}$ génotype n'était significative pour aucune des classes de protéines.

5. La plupart des corrélations phénotypiques des pourcentages de protéines du sérum avec les caractères de production n'étaient pas significatives. Le pourcentage de $\gamma_{2}$-globulines était en corrélation négative avec le poids corporel à 8 semaines.

Mots clés : Poule, nanisme, protéines du sérum, ponte.

\section{Introduction}

Differences have been observed between the serum protein fractions of normal and dwarf layers in White Leghorn and White Plymouth Rock at three consecutive ages (GraNDHI et al., 1975). In a paper concerning the possible differences in protein metabolism related to the $\mathrm{dw}$ gene it was suggested (Woon et al., 1971) that the protein tissues of dwarf chickens are of a different composition than those of non-dwarf chickens. Guillaume \& LARBIER (cited by Guillaume, 1976) demonstrated that there was an association between the sex-linked $\mathrm{dw}$ gene and higher protein anabolism per gram of tissue. Concerning the plasma level of uric acid, BANERJEE et al. (1981) related the higher value found in dwarf chicks to two possibilities : impaired renal clearance or higher protein catabolism.

The purpose of the present study was to detect the differences due to the $\mathrm{dw}$ gene on electrophoretic serum protein fractions. Phenotypic correlations between chosen productive traits and each serum protein within each genotype were also considered.

\section{Material and methods}

\section{A. Birds and experimental conditions}

The parents of the experimental chickens used in this study were Fayoumi-Cross males heterozygous for the sex-linked dwarf gene (Dwdw) and dwarf females (dw-) from the same strain in which the $d w$ gene had been incorporated over three generations by repeated backcrossing. Such a mating produced female chicks of which half carried the dw gene and half the normal allele Dw.

The chicks, were raised in electrically heated batteries from day old to 4 weeks of age, and then in deep litter brooders. Water and feed were given ad libitum both at the brooding and laying stages.

The diet contained 18 p. 100 protein and 2800 Kcal. M.E./kg during brooding and rearing while that given during the laying stage contained $16 \mathrm{p} .100$ protein and $2650 \mathrm{Kcal} \mathrm{M.E.} / \mathrm{kg}$. 
Trapnests were used to record the data related to sexual maturity and egg production. At 43 weeks of age, $35 \mathrm{dw}$ and $26 \mathrm{Dw}$ females belonging to 7 sire family groups were chosen for this experiment. Blood samples were collected from wing vein of non starved chickens. Samples were taken in the morning and serum samples for electrophoresis were obtained 24 hours later.

\section{B. Electrophoretic analysis of serum proteins}

Electrophoresis was performed on vertical PAGE slabs $(3 \times 126 \times 180 \mathrm{~mm})$ StegmanN (1979), using Tris-borate buffer (0.125 M, pH 8.9). A serum sample of $20 \mu l$ was mixed with sucrose and a trace of amido black added; each sample was applied to a slot. The run was conducted at 135 volts for 3 hours. To visualize protein fractions 1 p. 100 Coomassie Brilliant Blue R-250 was used. An ACD-15 automatic computing densitometer was used for quantitative measurements of bands at $550 \mathrm{~m} u$ wave length, and then each individual serum fraction was calculated as a percentage of total serum protein.

\section{Traits measured}

1. Body weight at 8 weeks of age, body weight and age at sexual maturity, egg number laid for 90 days after the onset of laying and the average egg weight during this period, were measured.

2. The percentages of the following serum protein fractions were estimated : albumin; $\alpha_{1}, \alpha_{2}, \beta_{1}, \beta_{2}, \gamma_{1}, \gamma_{2}$ globulins, total globulin and the albumin/globulin ratio.

\section{Statistical analysis}

Only the sire families including both dwarf and normal genotypes were chosen for statistical analysis. Analysis of variance of each trait was made considering the sire family and genotype as sources of variation. Phenotypic correlations were calculated for each percentage of serum protein fraction with different productive traits within each genotype separately. The homogeneity of the correlation coefficients was tested, then a mean value was estimated. Except correlations significantly different between dwarf and the normal genotype, only the mean correlation coefficients were tabulated.

\section{Results and discussion}

\section{A. Means and analysis of variance}

As the main purpose of this paper was to detect possible differences between dwarf and normal layers with regard to serum protein fractions and the association between the former and some selected productive traits, our discussion will be focused on the data concerning these fractions.

Means of the selected productive traits of the 2 genotypes, the per cent of dwarf relative to normal genotype for each trait and the analysis of variance are given in table 1. 
TABLE 1

Means and analyses of variance of body weight at 8 weeks, sexual maturity and egg production traits.

Moyennes et analyses de variance pour le poids à 8 semaines, la maturité sexuelle et les variables relatives à la production d'œufs.

\begin{tabular}{|c|c|c|c|c|c|c|}
\hline \multirow[b]{2}{*}{ Traits } & \multicolumn{3}{|c|}{ Mean value } & \multicolumn{3}{|c|}{ Analysis of variance - F - value } \\
\hline & $\begin{array}{c}\text { Dwarf } \\
\text { †? } \\
{[35]}\end{array}$ & $\begin{array}{c}\text { Normal } \\
\wp q \\
{[26]}\end{array}$ & $\frac{\mathrm{dw}-}{\mathrm{Dw}-} \%$ & $\begin{array}{c}\text { Genotype } \\
\text { (1) }\end{array}$ & $\begin{array}{l}\text { Sire- } \\
\text { Family } \\
\text { (6) }\end{array}$ & $\begin{array}{l}\text { Inter- } \\
\text { action } \\
(6)\end{array}$ \\
\hline Body weight at 8 weeks (g) & 305.1 & 434.4 & 70.23 & $36.81^{* * *}$ & $5.80 * *$ & 1.83 \\
\hline $\begin{array}{l}\text { Body weight at sexual ma- } \\
\text { turity }(g) \ldots \ldots \ldots \ldots \ldots\end{array}$ & 966.5 & 1576.1 & 61.32 & $105.30^{* * *}$ & 0.78 & 0.82 \\
\hline $\begin{array}{l}\text { Age at sexual maturity } \\
\text { (days) } \ldots \ldots \ldots \ldots \ldots \ldots\end{array}$ & 203.9 & 187.8 & 108.57 & $14.26 * *$ & 1.33 & 1.12 \\
\hline $\begin{array}{l}\text { Egg number (90 days after } \\
\text { sexual maturity) } \ldots \ldots \ldots \ldots\end{array}$ & 39.7 & 39.7 & 100.00 & 0.01 & 0.49 & 0.53 \\
\hline Average egg weight $(g) \ldots$ & 38.3 & 43.6 & 87.84 & $8.71 *:$ & 0.09 & 0.36 \\
\hline \multicolumn{7}{|c|}{$\begin{array}{l}\text { Residual d.f. }=47 . \\
{[]=\text { Number of hens per genotype. }} \\
(\text { ) }=\text { d.f. } \\
*: *=\text { Significant at the } 1 \text { p. } 100 \text { level. }\end{array}$} \\
\hline
\end{tabular}

The percentage of each serum protein fraction of dwarf and normal hens, the ratio between the mean value of dwarf hens and that of normal hens and the analysis of variance of these traits, are shown in table 2 .

Dwarf hens had a lower albumin percentage than their normal counterparts $(p<0.05)$. The reduction caused by the presence of the $\mathrm{dw}$ gene was about $8.1 \mathrm{p} .100$. Our result is in good agreement with that reported by GRANDHI et al. (1975), but the albumin percentage was different from our value, perhaps due to different breeds and/or electrophoresis techniques used in the 2 studies. Among the functions which are known for albumin, ButLeR (1983) demonstrated that about 75 p. 100 of Thyroxine $\left(\mathrm{T}_{4}\right)$ in chicken plasma is attached to albumin and about $10 \mathrm{p} .100$ to $\alpha$-globulin and the reminder to pre albumin. It is premature to speculate whether our result has a significance for the thyroid activity in dwarf birds. GRANDHI et al. (1975) observed a significant reduction in the uptake of iodine- 131 by the thyroid gland of dwarf layers, indicating that the thyroid activity in dwarf hens was significantly lower than in their normal counterparts. On the other hand, albumin plays an important role in plasma osmotic pressure regulation and therefore, the plasma volume and the tissue fluid balance (BUTLER, 1971). 


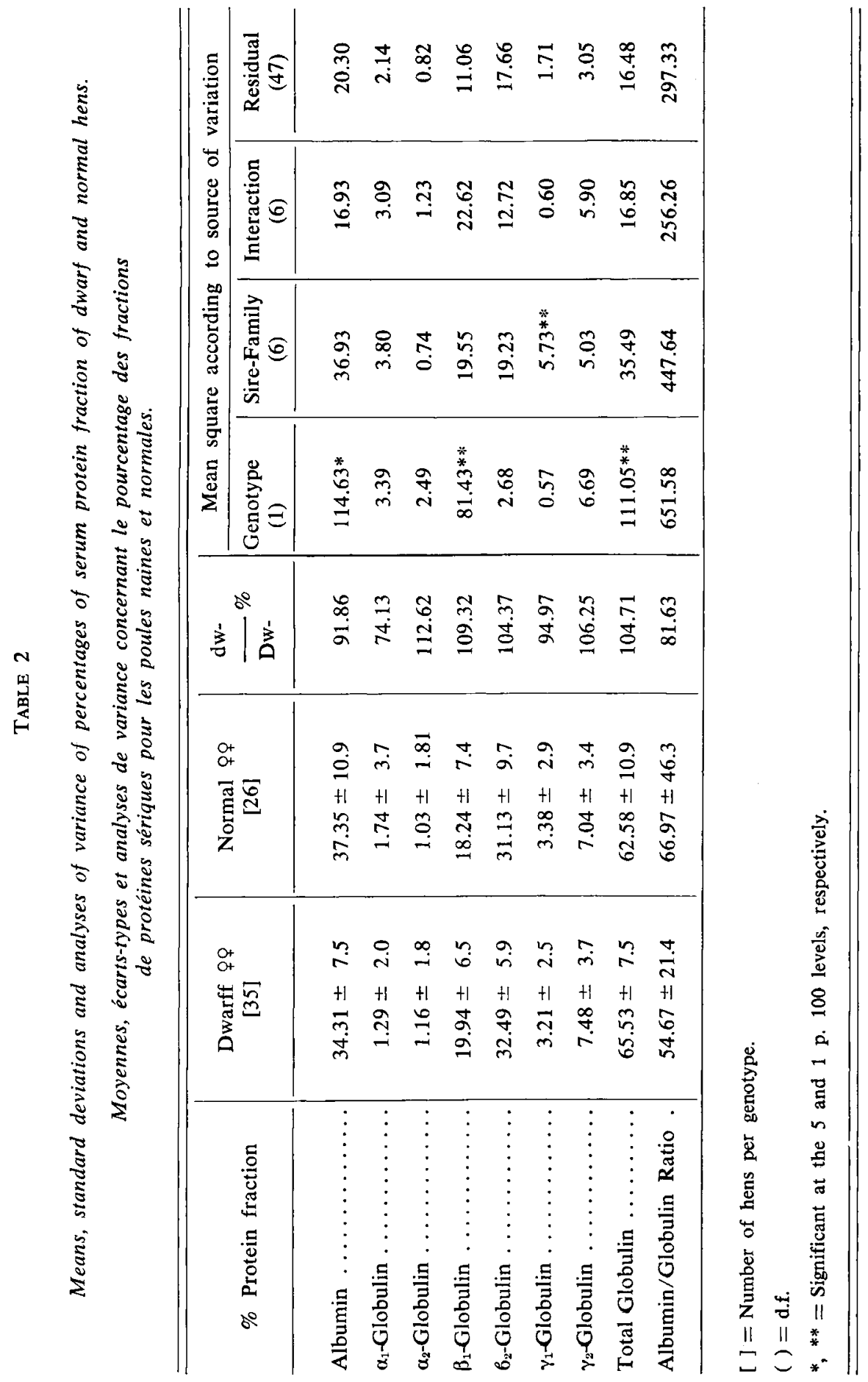


No significant differences were observed between sire families or due to the genotype $(\mathrm{Dw} / \mathrm{dw})$ either for the percentage of $\alpha_{1^{-}}$or $\alpha_{2}$-globulins. Our data may indicate that there is no significant difference between dwarf and normal hens for the concentration of ceruloplasmin, a copper binding serum protein associated with $\alpha_{2}$-globulin according to ButLer (1971). In contrast, a lower proportion of total $\alpha$-globulin was found in dwarf White Leghorn layers as compared with their normal sized equivalents (GRANDHI et al., 1975).

$\beta_{1}$-globulin p. 100 was significantly $(\mathrm{p}<0.01)$ higher in dwarf than in normal layers. Such a serum protein fraction includes transferrin which is responsible for the absorption and transport of iron from the intestine, suggesting a higher plasma transferrin concentration associated with the dw gene. MarTin \& JANDi (1959) suggested that the iron binding protein makes iron unavailable for multiplication of either viruses or bacteria.

Concerning the $\gamma_{1^{-}}$and $\gamma_{2}$-Globulins, the analysis of variance did not show any significant differences between dwarf and normal layers, while the percentage of these proteins was significantly affected by the sire family. When the $2 \gamma$-globulin fractions were combined, the percentage in dwarfs was 10.69 vs 10.42 in normal layers.

In contrast, GRANDHI et al. (1975) demonstrated that dwarf layers exhibited a significantly higher $\gamma$-globulin percentage thant that of the normal ones, suggesting that their antibody content was relatively higher than in normal layers.

According to our data, the dwarf layers had a higher total globulin p. 100 than the normal layers $(p<0.01)$. The increase of this protein fraction due to the $d w$ gene was about 2.95 p. 100 . No significant difference in the albumin/globulin ratio could be detected statistically between dwarf and non-dwarf females, although the Alb-Glob ratio was 54.67 and 66.97 p. 100 respectively for dwarf and normal hens.

\section{B. Phenotypic correlations}

The mean correlation coefficients between the productive traits and each serum protein fraction are given in table 3. Most of the correlation coefficients were homogenous except that concerning the body weight at sexual maturity and number of eggs produced with both $\beta_{1^{-}}$and $\gamma_{1}$-globulin fractions. No interpretation was available for these differences between $\mathrm{Dw}$ and $\mathrm{dw}$ genotypes.

The correlations were small and non significant for all traits studied except one. A significant negative correlation was found between body weight at 8 weeks and $\gamma_{2}$-globulin.

It is difficult at present to interpret the case where a correlation is found significant only in one genotype ; owing to the limited numbers they should await further confirmation.

Body weight at sexual maturity was only positively correlated $(\mathrm{p}<0.05)$ with $\beta_{2}$-globulin p. 100 in dwarf hens, but the same correlation in normal hens was opposite and non-significant. The negative association between $\gamma_{1}$-globulin and adult weight was only observed in dwarf hens $(p<0.05)$ while the contrary occurred in normal hens and was not significant. 


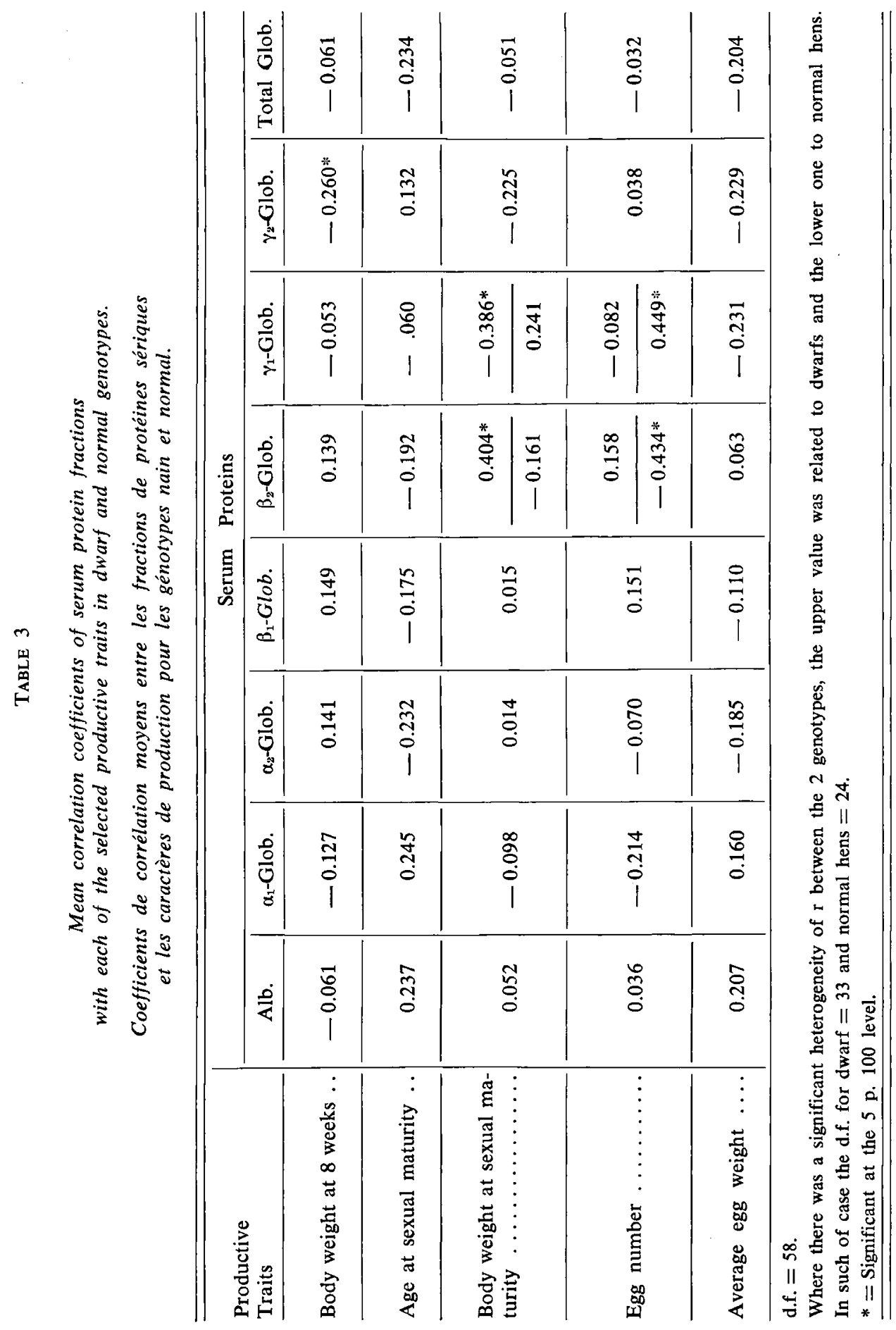


With respect to the relationship between the number of eggs produced for 90 days after sexual maturity and each serum protein percentage, a significant negative association was found only for the Dw genotype with $\beta_{2}$-globulin while that related to $\mathrm{dw}$ - had a positive value and was non-significant. There is no obvious physiological explanation of the difference between the two genotypes.

It has been well established that phosvitin is involved in iron, calcium and phosphorus transport in yolk and shell formation. Since this protein migrates with $\gamma$-globulin molecules (BUTLER, 1971), the differences in the correlations between the egg number and $\gamma_{1}$-globulin found in the 2 genotypes might suggest a difference between dw and Dw genotyppes in the binding activity of $\gamma$-globulin molecules with phosvitin.

\section{Acknowledgements}

We would like to thank Dr. P. Merat, Head of the «Laboratoire de Génétique factorielle, Centre National de Recherches zootechniques, 78350 Jouy-en-Josas, France», for his very useful criticism of this manuscript.

Received January 27, 1984.

Accepted September 5, 1984.

\section{References}

Banerjee A.K., Bordas A., Merat P., 1981. The effect of temperature and genotype on growth traits, plasma glucose and uric acid in dwarf and normal White Leghorn females. Ann. Génét. Sél. Anim., 13, 255-268.

Butler E.J., 1971. Plasma proteins, in Bell D.J., Freeman B.M. (ed.), Physiology and Biochemistry of the Domestic Fowl, 933-961, Academic Press, London.

Butler E.J., 1983. Plasma proteins, in Bell D.J., Freeman B.M. (ed.), Physiology and Biochemistry of the Domestic Fowl, 321-337, Academic Press, London.

Grandhi R.R., Brown R.G., Reinhart B.S., Summers J.D., 1975. Thyroid metabolism in the recessive sex-linked dwarf female chicken. 2-binding of thyroid hormones by serum proteins. Poult. Sci., 54, 493-499.

Guillaume J., 1976. The dwarfing gene dw : its effects on anatomy, physiology, nutrition, management. Its application in poultry industry. World's Poult. Sci. J., 32, 285-304.

MARTIN C.M., JANDI J.H., 1959. Inhibition of virus multiplication by transferrin. J. Clin. Invest., 38, 1024 (abstr.).

StegmanN H., 1979. Electrophoresis and focusing in slabs using the Pantaphor apparatus for analytical and preparative separations in gel (Polyacrylamide, agarose, starch, sephadex), 29 pp., Institute of Biochemistry, Messeweg 11, D-3300 Braunschweig, West-Germany.

StURKIE P.D., EPBC. Avian physiology. 3rd ed., 400 pp., Springer, New York.

Wood A.S., Brown R.G., Summers J.D., ReinharT B.S., 1971. An aspect of protein biosynthetic activity by the dwarf and non-dwarf White Leghorn chicken. Poult. Sci., 50, 982.-984. 